\title{
Mapping TRPM7 Function by NS8593
}

\author{
Vladimir Chubanov * (D) and Thomas Gudermann* \\ Walther-Straub Institute of Pharmacology and Toxicology, Faculty of Medicine, \\ Ludwig-Maximilians Universität München, 80336 Munich, Germany \\ * Correspondence: vladimir.chubanov@lrz.uni-muenchen.de (V.C.); \\ thomas.gudermann@lrz.uni-muenchen.de (T.G.); Tel.: +49-89-2180-75740 (V.C.); +49-89-2180-75702 (T.G.)
}

Received: 1 September 2020; Accepted: 21 September 2020; Published: 23 September 2020

\begin{abstract}
The transient receptor potential cation channel, subfamily M, member 7 (TRPM7) is a ubiquitously expressed membrane protein, which forms a channel linked to a cytosolic protein kinase. Genetic inactivation of TRPM7 in animal models uncovered the critical role of TRPM7 in early embryonic development, immune responses, and the organismal balance of $\mathrm{Zn}^{2+}, \mathrm{Mg}^{2+}$, and $\mathrm{Ca}^{2+}$. TRPM7 emerged as a new therapeutic target because malfunctions of TRPM7 have been associated with anoxic neuronal death, tissue fibrosis, tumour progression, and giant platelet disorder. Recently, several laboratories have identified pharmacological compounds allowing to modulate either channel or kinase activity of TRPM7. Among other small molecules, NS8593 has been defined as a potent negative gating regulator of the TRPM7 channel. Consequently, several groups applied NS8593 to investigate cellular pathways regulated by TRPM7. Here, we summarize the progress in this research area. In particular, two notable milestones have been reached in the assessment of TRPM7 druggability. Firstly, several laboratories demonstrated that NS8593 treatment reliably mirrors prominent phenotypes of cells manipulated by genetic inactivation of TRPM7. Secondly, it has been shown that NS8593 allows us to probe the therapeutic potential of TRPM7 in animal models of human diseases. Collectively, these studies employing NS8593 may serve as a blueprint for the preclinical assessment of TRPM7-targeting drugs.
\end{abstract}

Keywords: TRPM7; NS8593; naltriben; calcium; magnesium; zinc

\section{Introduction}

TRPM7 has been cloned and functionally characterized two decades ago [1-3]. Since then, extensive investigations have been conducted to clarify the molecular and organismal aspects of the TRPM7 function [4]. The outcome of these studies has been comprehensively discussed in a number of recent review articles [5-11]. Here, we briefly highlight the key findings to outline the progress in this fascinating research field.

\section{Functional Characteristics and Physiological Roles of TRPM7}

TRPM7 encodes a bi-functional protein comprising a TRP-type transmembrane channel unit fused to a C-terminal $\alpha$-type serine/threonine-protein kinase domain [1-3]. Similarly to other TRP channels, the channel-coding segment of TRPM7 comprises six transmembrane helixes with a channel pore-forming sequence located between the fifth and six helices (Figure 1A,B). Four TRPM7 proteins assemble in a symmetric channel complex (Figure 1C) [1-3]. Hence, one TRPM7 channel moiety is linked to four cytosolic kinase domains. Among other known channels and kinases, only TRPM7 and its homologous protein TRPM6 are known as channels covalently fused to protein kinase domains [12-15]. The crystal structure of the C-terminal TRPM7 domain revealed the three-dimensional packing of the catalytic domain of the kinase [16]. More recently, cryo-electron microscopy of the truncated TRPM7 
protein (lacking the kinase domain) clarified the role of distinct amino acid residues for the tetrameric assembly of the channel segment (Figure 1B,C) [17]. However, the positioning of the kinase and channel units relative to each other in the full-length TRPM7 protein, as well as distinct rearrangements in TRPM7 folding during channel gating, remain unknown [18].
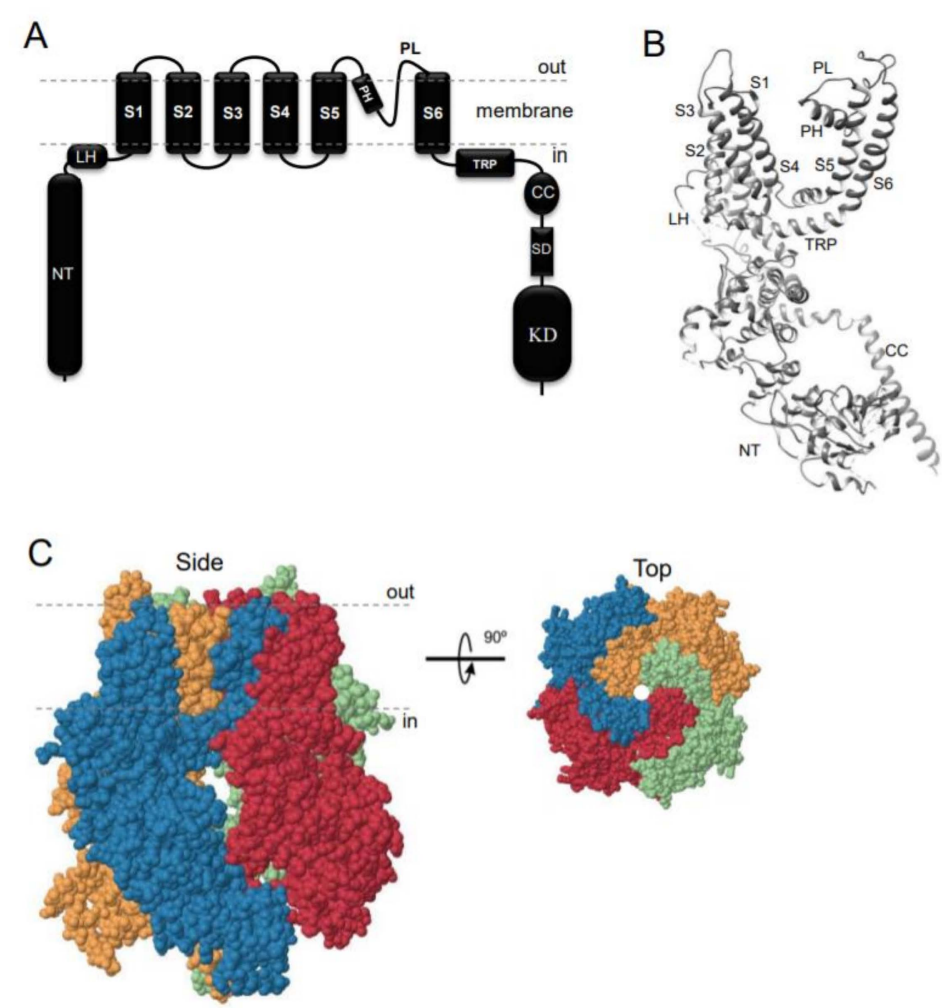

Figure 1. Domain topology and tetrameric assembly of the kinase-coupled channel TRPM7. (A) TRPM7 comprises a large cytosolic N-terminal domain (NT), a linker-helical domain (LH), six transmembrane helices (S1-S6), a pore-forming pore helix (PH) and loop (PL), a transient receptor potential domain (TRP), a coiled-coil domain (CC), a kinase substrate domain (SD) and a kinase domain (KD). (B) Ribbon diagram of a single TRPM7 channel subunit produced from 6BWD using UCSF Chimera (www.cgl.ucsf.edu). (C) Tetrameric TRPM7 channel complex (6BWD) Four channel subunits of TRPM7 are labeled by different colors and shown from the side and top views.

In pioneering patch-clamp experiments, endogenous TRPM7 currents were referred to as magnesium nucleotide-regulated metal ion currents (MagNuM) [1,19] and magnesium-inhibited cation currents (MIC) [20], and were later called TRPM7-like or TRPM7 currents [5-11]. Such native TRPM7 currents were monitored in a large variety of primary isolated cells and stable cell lines [5-11]. In accord with biophysical experiments, TRPM7 transcripts were found to be abundantly present in all native tissues examined [5-11]. TRPM7 was defined as a constitutively active cation channel highly selective for divalent cations such as $\mathrm{Zn}^{2+}, \mathrm{Ca}^{2+}$ and $\mathrm{Mg}^{2+}$ [1-3]. Among other factors, cytosolic magnesium (free $\mathrm{Mg}^{2+}$ or in complex $\mathrm{Mg} \cdot \mathrm{ATP}$ ) and the plasma membrane phospholipid phosphatidylinositol-4,5-bisphosphate ( $\left.\mathrm{PIP}_{2}\right)$ were discovered as prime physiological regulators of TRPM7 [1-3,21]. While intracellular $\mathrm{Mg}^{2+}$ or Mg.ATP directly act as negative regulators of the channel, receptor-dependent phospholipase $\mathrm{C}$ activation, and resultant $\mathrm{PIP}_{2}$ depletion indirectly result in TRPM7 inactivation [1-3,21].

Genetic disruption of TRPM7 in cultured cells revealed that the TRPM7 channel is key to the homeostatic balance of divalent cations including $\mathrm{Zn}^{2+}, \mathrm{Mg}^{2+}$ and $\mathrm{Ca}^{2+}[14,22-26]$, cell motility [27-34], proliferation [1,23,24,35-37], differentiation [38,39], $\mathrm{Ca}^{2+}$ signaling events [40,41] and an ever growing number of other cellular processes [5-11]. Pathophysiological implications of TRPM7 are widespread 
and include anoxic neuronal death [42], hypertension [43,44], neurodegenerative disorders [45,46], tissue fibrosis [47-50], tumour growth/progression [51-58] and abnormal immune responses [59]. Genetic association studies in humans revealed that point mutations in the TRPM7 gene cause a giant platelet disorder (macrothrombocytopenia) [60]. Experiments with mice currying a global or tissue-specific null mutation in the Trpm7 locus showed that TRPM7 is required for early embryonic development [22,61-64], thymopoiesis [61], morphogenesis of the kidney [63], cardiac rhythmicity and repolarization [65], systemic homeostasis of $\mathrm{Zn}^{2+}, \mathrm{Mg}^{2+}$ and $\mathrm{Ca}^{2+}[22,66]$, thrombopoiesis [60], and mast cell degranulation [67].

The list of phosphorylation substrates of the TRPM7 kinase is extensive and surprisingly heterogeneous in terms of possible biochemical pathways affected. Thus, TRPM7 kinase can phosphorylate TRPM6 [68], annexin A1 [69], myosin II isoforms [70], eukaryotic elongation factor-2 kinase (eEF2-k) [71], tropomodulin [72], phospholipase C gamma 2 (PLC $\gamma 2$ ) [73], stromal interaction molecule 2 (STIM2) [25], Mothers against decapentaplegic homolog 2 (SMAD2) [59], and Ras homolog family member A (RhoA) [74]. Furthermore, multiple serine/threonine residues positioned in a 'substrate' segment of TRPM7 are autophosphorylation targets of the kinase domain [11,75-77]. In immune cells, the TRPM7 kinase domain can be cleaved from the channel complex by caspases during Fas-receptor stimulation [35]. Another study reported that the cleaved TRPM7 kinase can be detected in several cell lines and that the released kinase is able to translocate into the cell nucleus to phosphorylate histones [78]. The in vivo relevance of these reactions remains to be verified, because, unlike to the mouse strains with the Trpm 7 null mutation, animals carrying the 'kinase-dead' point mutation were found to be fertile, and displayed normal pre- and postnatal development, if maintained under regular conditions $[59,66,79,80]$.

\section{Drug-like Modulators the Channel and Kinase Activity of TRPM7}

In light of the bi-functional nature of TRPM7, there is a growing demand for reliable drug-like molecules allowing for selective and distinct modulation of its channel and kinase moieties. Initially, agents acting as unspecific channel inhibitors, such as spermine [20], ruthenium red [81], trivalent cations [82], SKF-96365 [20] and 2-aminoethyl diphenylborinate (2-APB) [83], were used to block the TRPM7 channel. Subsequently, several drug-like molecules were reported as inhibitors of the TRPM7 channel effective only in a high $\mu \mathrm{M}$ range, such as nafamostat [84], carvacrol [85-89], 5-lipoxygenase inhibitors (NDGA, AA861 and MK886) [90-93], midazolam [94,95], ginsenoside Rg3 [96], ginsenoside-Rd [97,98], aripiprazole [99] and coomassie brilliant blue G-250 (BBG) [100]. Our laboratory identified several additional inhibitors of the TRPM7 channel such as quinine, CyPPA, dequalinium, SKA31, and UCL1684 [101].

In contrast to later molecules, Waixenicin A, FTY720 and NS8593 were able to suppress TRPM7 currents when applied at low $\mu \mathrm{M}$ concentrations. Subsequently, these reagents were often used to probe the cellular role of TRPM7 [102,103]. Waixenicin A is a natural terpenoid isolated from the soft coral Sarcothelia edmondsoni, and inactivates the TRPM7 channel in an $\mathrm{Mg}^{2+}$ dependent manner with an $\mathrm{IC}_{50}$ of $7 \mu \mathrm{M}$ [37]. FTY720 (synthetic homolog of sphingosine) inhibited TRPM7 currents with an $\mathrm{IC}_{50} 0.7 \mu \mathrm{M}$ [104]. Our laboratory has shown that the small synthetic molecule $\mathrm{N}-[(1 \mathrm{R})-1,2,3,4$-tetrahydronaphthalen-1-yl]-1H-benzimidazol-2-amine (NS8593, Figure 2) suppresses TRPM7 currents in an $\mathrm{Mg}^{2+}$-dependent fashion with an $\mathrm{IC}_{50}$ of $1.6 \mu \mathrm{M}$ [101]. 
A

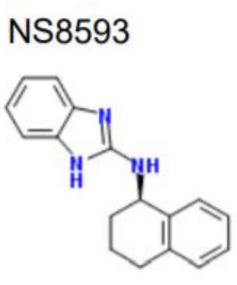

C

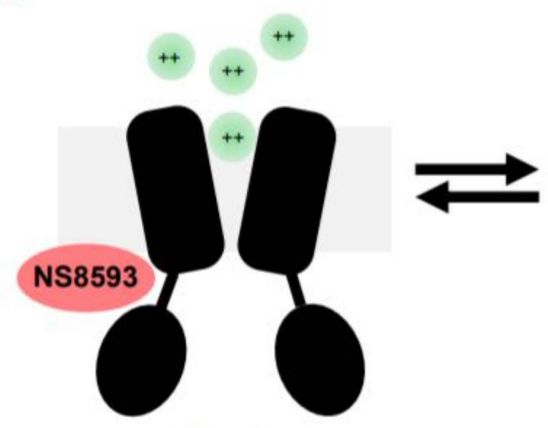

Closed
B

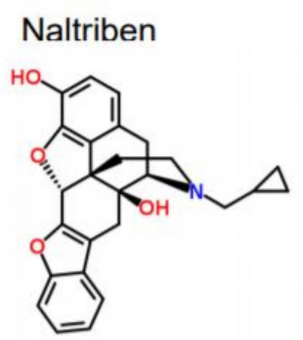

Figure 2. Chemical structures and mode of action of NS8593 and naltriben on the TRPM7 channel. (A) NS8593 chemical structure. (B) Naltriben chemical structure. (C)The TRPM7 channel is depicted in the closed and open states. NS8593 acts as negative gating modulator of the channel, whereas naltiben triggers opening of TRPM7 and influx of divalent cations (green balls) into the cell.

In a follow-up screen, our group has discovered the first small drug-like molecules functioning as TRPM7 channel agonists [105]. In particular, we found that twenty drug-like compounds with different structural backbones can stimulate TRPM7 currents [105,106]. Among them, naltriben (Figure 2) and mibefradil were characterized more in detail, and nowadays both compounds are frequently used by other TRPM7 investigators, often in combination with the TRPM7 inhibitors mentioned before $[102,103]$. Of note, naltriben is able to activate the TRPM7 channel both in the presence of physiological concentrations of cytosolic $\mathrm{Mg}^{2+}$ and after $\mathrm{PIP}_{2}$ depletion with an $\mathrm{EC}_{50}$ of $20 \mu \mathrm{M}$ [105]. Hence, we defined naltriben as a positive gating modulator of the TRPM7 channel [105]. Unlike naltriben, mibefradil-mediated activation of TRPM7 was highly dependent on intracellular $\mathrm{Mg}^{2+}$ levels [106]. Accordingly, we suggested that at least two distinct types of TRPM7 activators exist, referred to as type 1 (acting independently of $\mathrm{Mg}^{2+}$ ) and type $2\left(\mathrm{Mg}^{2+}\right.$-dependent agonists) [106].

Overall, the pharmacological toolkit suitable for the assessment of the TRPM7 kinase remains underdeveloped, and currently, it is limited to only one compound, TG100-115. TG100-115 was initially introduced as an inhibitor of phosphoinositide 3-kinases [107]. However, Davis et al. [108] found that TG100-115 is also able to inactivate the purified kinase domain of TRPM6 with an IC $_{50}$ of $8 \mathrm{nM}$ [108]. We also found that TG100-115 efficiently inactivates TRPM6 kinase in living cells [21]. Besides, Song et al. [109] examined the effects of TG100-115 on the TRPM7 kinase and reported that this reagent inhibits the TRPM7 kinase with an $\mathrm{IC}_{50}$ of $2 \mu \mathrm{M}$. Finally, it is worth mentioning that in our hands, neither NS8593 nor naltriben directly affected the kinase activity of TRPM7 (unpublished observations). However, we cannot rigorously exclude that in specific experimental settings, these compounds may modulate the kinase moiety indirectly, for instance subsequent to altered uptake of divalent cations by the channel domain of TRPM7.

\section{NS8593 as a Tool to Investigate the Function of TRPM7 Currents}

As mentioned above, the small synthetic compound NS8593 was identified as a potent inhibitor of the TRPM7 channel [101]. In recent years, numerous independent studies have been conducted, 
and NS8593 was successfully used to probe the role of TRPM7 in various cellular processes (Table 1). Overall, these results have made significant inroads into our understanding of the druggability of the TRPM7 channel and highlighted several pathophysiological conditions, which can be modulated by TRPM7 inhibitors.

Table 1. Cellular processes affected by NS8593.

\begin{tabular}{|c|c|c|}
\hline Cell Type/Tissue & Effects of NS8593 & References \\
\hline $\begin{array}{c}\text { HEK293, } \\
\text { primary microglia, } \\
\text { A172 glioblastoma cells }\end{array}$ & Motility/chemotaxis & $\begin{array}{l}{[101]} \\
{[110]} \\
{[111]}\end{array}$ \\
\hline $\begin{array}{l}\text { Primary ventricular myocytes, } \\
\text { primary vascular smooth muscle cells, } \\
\text { HT29 epithelial colon cells }\end{array}$ & $\mathrm{Mg}^{2+}$ homeostasis & $\begin{array}{c}{[112,113]} \\
{[114]} \\
{[115]}\end{array}$ \\
\hline $\begin{array}{l}\text { Mouse oocytes and eggs, } \\
\text { DT40 B lymphocytes, } \\
\text { primary enamel cells, } \\
\text { 3T3-L1 fat cells }\end{array}$ & $\begin{array}{l}\mathrm{Ca}^{2+} \text { uptake, intracellular } \mathrm{Ca}^{2+} \\
\text { stores and } \mathrm{Ca}^{2+} \text { signalling }\end{array}$ & $\begin{array}{c}{[41,116]} \\
{[117]} \\
{[118]} \\
{[119]}\end{array}$ \\
\hline $\begin{array}{l}\text { MDA-MB-231 breast cancer cells, } \\
\text { A172 glioblastoma cells }\end{array}$ & Proliferation/cell cycle & $\begin{array}{l}{[120]} \\
{[111]}\end{array}$ \\
\hline MDA-MB-468 breast cancer cells & Differentiation & [121] \\
\hline $\begin{array}{l}\text { Primary B cells, } \\
\text { mouse erythrocytes } \\
\text { primary microglia } \\
\text { primary macrophages }\end{array}$ & Immune responses & $\begin{array}{l}{[122]} \\
{[123]} \\
{[120]} \\
{[110]}\end{array}$ \\
\hline HuH7 hepatocellular carcinoma in a xenograft mouse model & Tumour growth & [74] \\
\hline Kidneys & Fibrosis & [49] \\
\hline
\end{tabular}

Initially, NS8593 was identified as a potent negative gating modulator of small conductance $\mathrm{Ca}^{2+}$-activated $\mathrm{K}^{+}$channels (SK1-3 or $\mathrm{K}_{\mathrm{ca}} 2.1-2.3$ channels) [123]. The inhibitory effect of NS8593 was pronounced at low intracellular $\mathrm{Ca}^{2+}$ concentrations and abolished at $30 \mu \mathrm{M} \mathrm{Ca}^{2+}$ [123]. It turned out that NS8593 is also able to suppress TRPM7 currents in an analogous manner [101]. Thus, the effect of NS8593 on TRPM7 is modulated by cytosolic $\mathrm{Mg}^{2+}$ levels, because the $\mathrm{IC}_{50}$ value of NS8593 determined in the absence of $\mathrm{Mg}^{2+}(1.6 \mu \mathrm{M})$ was increased $\sim 4$-fold in the presence of $300 \mu \mathrm{M} \mathrm{Mg}^{2+}$ [101]. The inhibition of TRPM7 currents by NS8593 was voltage-independent. Importantly, the effect of NS8593 was fast, reversible, and repeatable, suggesting that the interaction of NS8593 with TRPM7 neither induces irreversible modifications of the protein nor affects the cell surface localization of TRPM7 [101]. Patch-clamp experiments with a subset of primary cell models (freshly isolated smooth muscle cells, primary mouse podocytes, and primary human ventricular myocytes) demonstrated that NS8593 efficiently blocks endogenous TRPM7 currents [101]. Notably, a highly specific inhibitor of SK channels, apamin, showed no effect on the biophysical characteristics of TRPM7 and can, therefore, be used for sorting-out off-target effects of NS8593 in cells expressing both channel species [101]. Finally, long-term exposure of cultured cells to NS8593 showed that this compound elicits sustained effects on TRPM7 [101]. For instance, the addition of NS8593 (but not apamin) to the cell culture medium suppressed endogenous TRPM7 currents and motility of HEK293 cells, replicating one of the prominent effects of siRNA silencing of TRPM7 [101]. Collectively, these findings suggested that NS8593 acts as a negative gating modulator of the TRPM7 channel (Figure 2B), and that NS8593 is well suitable for blocking endogenous TRPM7 channels in different experimental settings.

In follow up studies, many researchers used NS8593, frequently in combination with other TRPM7 modulators or RNAi silencing, to characterize the role of TRPM7 in particular cellular pathways (Table 1). For example, Davis et al. [120] employed NS8593 to study the mechanisms of epithelial-mesenchymal transition (EMT) of MDA-MB-468 breast cancer cells. The authors conducted siRNA-based screens and identified the TRPM7 channel as a critical regulator of epidermal growth 
factor (EGF)- or hypoxia-induced STAT3 phosphorylation and of the expression of the EMT marker vimentin in a $\mathrm{Ca}^{2+}$-dependent fashion. Accordingly, siRNA silencing of TRPM7 or application of NS8593 suppressed EGF-induced EMT in MDA-MB-468 cells [120]. Tumour necrosis factor-related apoptosis-inducing ligand (TRAIL) can selectively induce apoptosis in various types of cancer cells. Song et al. [124] investigated whether TRPM7 knockdown or pharmacological inhibition of the channel can enhance TRAIL-induced apoptosis in triple-negative breast cancer cells (MDA-MB-231 and MDA-MB-468). Among other findings, the authors demonstrated that pharmacological inhibition of the channel or kinase units in TRPM7 using NS8593 and TG100-115, respectively, synergistically increases TRAIL-induced apoptosis in breast cancer cells [124].

Among the critical microglial responses to brain injury is the activation and migration of microglia cells to the sites of injury. Lipopolysaccharide (LPS)- and interleukin-induced microglial activation is associated with characteristic changes in transcriptional profiles, production of inflammatory mediators, and increased motility of microglial cells. Siddiqui et al. [119] used NS8593 to illustrate that TRPM7 is required for interleukin- 4 and -10 (IL-4, -10$)$ induced motility of primary rat microglial cells. These findings are in line with the study of Schilling et al. [110], who demonstrated that TRPM7 inhibitors NS8593 or FTY720 suppressed proliferation of bone-marrow-derived macrophages induced by IL-4 and macrophage colony-stimulating factor (M-CSF). In addition, NS8593 and FTY720 prevented polarisation of primary macrophages towards the anti-inflammatory phenotype [110].

Nörenberg et al. [100] used NS8593 to show that TRPM7 regulates ATP-induced currents, which were previously thought to be conducted by the P2X7 channel. P2X7 mediates nonselective cation currents that are typically elicited by high concentrations of extracellular ATP. Nörenberg et al. [100] re-examined such ATP-induced currents in HEK293 and rat glioma C6 cells and concluded that TRPM7 is the correct molecular correlate of ATP-induced currents. In another study, Sadowska et al. employed NS8593 to rule out the involvement of TRPM7 in $\mathrm{Ca}^{2+}$-dependent osmosensing of nucleus pulposus cells [125].

Krishnamoorthy et al. [121] took advantage of NS8593 to demonstrate that TRPM7 controls antigen internalization and presentation in B cells. The DT40 B cell line deficient in the TRPM7 gene was unable to aggregate antigen after activation likely due to abnormal phospholipase $C$ (isoform $\gamma 2$ ) signalling and altered lipid metabolism. These results were recapitulated in primary mouse B cells expressing only a single allele of Trpm7 or after treatment by NS8593. The authors suggested TRPM7 controls an essential process required for B cell affinity maturation and the production of high-affinity antibodies [121].

Prostaglandin E2 (PGE2) plays a role in the migration and proliferation of human glioblastoma cells [111]. Tian et al. [111] observed that PGE2 increased TRPM7 currents in human glioblastoma A172 cells. Knockdown of TRPM7 by shRNA or exposure of cells to NS8593 abrogated PGE2-stimulated motility and proliferation of A172 cells [111]. Zou et al. [114] used NS8593 as one of the tools to establish an interplay between TRPM7 and epidermal growth factor receptor (EGFR) signalling in vascular smooth muscle (VSMC) cells. The study was conducted in primary VSMCs from rats and humans treated by NS8593 or cells from vascular tissues of Trpm7-modified mice. Zou et al. [114] found that EGFR directly interacts with TRPM7. This interaction regulated cytosolic $\mathrm{Mg}^{2+}$ levels, ERK1/2 signalling, and vascular tissue homeostasis.

Plasmodium falciparum causes the most harmful form of malaria in humans. The parasite invades erythrocytes and triggers complex responses due to multiple ligand-receptor interactions leading to the abnormal assembly of cytoskeletal proteins [122]. Intriguingly, Sisquella et al. [122] have shown that NS8593, as well as other TRPM7 blockers (FTY720 and waixenicin), fully inhibit parasite invasion and changes in deformability of erythrocytes suggesting that TRPM7 might be a promising target of new antimalarial drugs.

Independent studies with TRPM7 gene-deficient cells revealed a critical role of TRPM7 in the cellular balance of $\mathrm{Mg}^{2+}[14,22-26]$. In line with this idea, several laboratories could show that NS8593 interferes with TRPM7-mediated uptake of $\mathrm{Mg}^{2+}$. For instance, Tashiro et al. [112,113] employed 
NS8593 in combination with naltriben to illustrate that TRPM7 controls $\mathrm{Mg}^{2+}$ influx in primary rat ventricular myocytes. Thus, endogenous TRPM7 currents were abundantly present in primary cells and were fully blocked by NS8593. In line with these findings, application of NS8593 lowered levels of cytosolic $\mathrm{Mg}^{2+}$. The authors also noted that naltriben significantly raised cellular levels of $\mathrm{Mg}^{2+}$ after the removal of extracellular $\mathrm{Na}^{+}$to offset the activity of $\mathrm{Na}^{+} / \mathrm{Mg}^{2+}$ exchangers. However, re-introduction of extracellular $\mathrm{Na}^{+}$lowered $\mathrm{Mg}^{2+}$ concentrations to the basal level. The authors concluded that $\mathrm{Mg}^{2+}$ entry through TRPM7 significantly contributes to $\mathrm{Mg}^{2+}$ homeostasis in mammalian heart cells $[112,113]$. In another study, Luongo at al. [115] used NS8593 to illustrate such a role of TRPM7 in human epithelial colon cells. Interestingly, colon carcinoma HT29 and HCT116 cells express the two homologous proteins TRPM6 and TRPM7. NS8593 treatment or TRPM7 silencing by RNAi suppressed cell proliferation and $\mathrm{Mg}^{2+}$ influx in both HT29 and HCT116 cells, while downregulation of TRPM6 did not significantly affect either $\mathrm{Mg}^{2+}$ influx or cell proliferation [115].

NS8593 was also instrumental in studies investigating the contribution of TRPM7 to $\mathrm{Ca}^{2+}$ signalling events. It is well established that repetitive oscillations in cytoplasmic $\mathrm{Ca}^{2+}$ due to periodic influx of $\mathrm{Ca}^{2+}$ drive mammalian embryo development following fertilization. Carvacho et al. [41] and Bernhardt et al. [116] focused on the identification of channels controlling such mechanisms. Thus, Carvacho et al. [41] detected TRPM7 currents in immature mouse oocytes (germinal vesicle stage), matured oocytes (metaphase II eggs) and 2-cell stage embryos. Currents were activated by natriben and inhibited by NS8593. Activation of TRPM7 induced $\mathrm{Ca}^{2+}$ influx in oocytes and eggs to support fertilization and egg activation. Application of NS8593 delayed pre-implantation embryo development and reduced progression to the blastocyst stage. This concept was further supported by the study of Bernhardt et al. [116] showing that fertilization-induced $\mathrm{Ca}^{2+}$ oscillations in mouse oocytes and eggs were also impaired by NS8593 treatment. Hence, both studies suggest that TRPM7 may contribute to $\mathrm{Ca}^{2+}$ influx in post-fertilization oocytes, eggs, and in embryonic development in mice.

In various cells, $\mathrm{Ca}^{2+}$ release from the endoplasmic reticulum engages calcium release-activated calcium channels (CRAC), a process that is entitled as store-operated calcium entry (SOCE). Two recent studies reviled that TRPM7 may be functionally connected to these pathways. Faouzi et al. [25] found that TRPM7 gene-deficient DT40 B lymphocytes exhibit impaired SOCE. In accord, blockade of TRPM7 with NS8593 or waixenicin A in wild-type cells results in a reduced SOCE. Using DT40 cells expressing a kinase-deficient mutant of TRPM7, Faouzi et al. [25] showed that TRPM7 regulates SOCE through its kinase domain. In line with these findings, NS8593 in combination with naltriben and siRNA approach was instrumental in demonstrating that in rat primary enamel cells and murine ameloblast LS8 cells TRPM7 acts as a positive regulator of SOCE and that this function of TRPM7 is dependent on ORAI1/2 channels, known molecular correlates of SOCE [117].

In adipocytes, cytosolic $\mathrm{Ca}^{2+}$ regulates insulin responses and the secretion of adipokines. Inoue et al. [118] investigated whether TRPM7 contributes to $\mathrm{Ca}^{2+}$ influx in freshly isolated white adipocytes and in 3T3-L1 adipocytes differentiated from 3T3-L1 pre-adipocyte cells. The authors used NS8593 together with FTY720, naltriben and siRNA techniques to show that the TRPM7 channel is functionally expressed in adipocytes. The authors conclude that TRPM7 plays a role as a $\mathrm{Ca}^{2+}$ influx pathway in adipocytes [118].

\section{Assessment of NS8593 Effects in Animal Models}

Originally, NS8593 was described as the selective blocker of SK channels, which are abundantly expressed in the heart and considered as a new therapeutic target for the treatment of atrial fibrillation (AF). Accordingly, NS8593 was tested in several ex vivo and in vivo models of AF. For example, in a rat model of AF, injection of NS8593 $(5 \mathrm{mg} / \mathrm{kg}$ ) shortened AF duration equally to amiodarone (known anti-AF drug) [126]. Similarly, injection of NS8593 (5 mg/kg) was found to be beneficial in AF models in dogs and horses $[127,128]$. While the specific contribution of SK channels vs. TRPM7 in such anti-AF effects remains to be elucidated $[129,130]$, these studies clearly showed that living animals could well tolerate the systemic administration of NS8593. 
More recently, NS8593 was used to assess TRPM7 as a new anti-fibrotic pharmacological target (Table 1). Expression of TRPM7 was found to be upregulated in fibrotic tissues of lung, liver and heart fibrosis [50,131-134]. TRPM7 expression was also increased after renal ischemia-reperfusion leading to kidney injury and fibrosis [135,136]. Recently, Suzuki et al. [49] investigated the unilateral ureteral obstruction (UUO) mouse model and observed that TRPM7 expression was elevated in UUO kidneys. Intraperitoneal injection of NS8593 (7 days; $5 \mathrm{mg} / \mathrm{kg} /$ day) prevented kidney atrophy in UUO kidneys, retained tubular formation, and reduced TRPM7 expression to normal levels. Mechanistically, the authors suggested that TRPM7 affects tissue fibrosis via the TGF- $\beta 1 /$ Smad network. The authors propose that pharmacological targeting of TRPM7 may be used to suppress kidney fibrosis [49].

As discussed above, TRPM7 inhibitors showed anti-proliferative effects on many cultured tumour-derived cells. Recently, our laboratory explored hepatocellular carcinoma HuH7 cells in a xenograft mouse model to assess the efficiency of NS8593 to suppress tumour progression (Table 1) [74]. Thus, we treated nude mice bearing xenografts derived from HuH7 cells systemically by intravenous injection of NS85936 (6 mg/kg every 2nd day, 17 days) and observed profoundly reduced tumour growth in NS85936-treated mice when compared with control animals [74]. Further experiments with multiple cell models revealed that the anti-tumour effect of NS8593 relies on TRPM7 channel-mediated $\mathrm{Mg}^{2+}$ influx and phosphorylation of RhoA by TRPM7 kinase [74].

\section{Conclusions}

Several structurally unrelated pharmacological modulators of TRPM7 have been identified, including NS8593 - a commercially available potent inhibitor of the TRPM7 channel. NS8593 was found to be instrumental in a broad range of experimental settings such as transient inactivation of TRPM7 currents in patch-clamp measurements, sustained treatment of cultured cells, and administration of the compound to living mice. Pharmacological targeting of TRPM7 by NS8593 in conjunction with genetic silencing of the whole TRPM7 protein or comparative analysis of effects induced by structurally unrelated TRPM7 modulators were shown to be instrumental in uncovering new cellular functions of TRPM7 and assessing the therapeutic potential of anti-TRPM7 drugs. Accordingly, these experiments can be regarded as a blueprint for the further development of high-affinity in vivo drugs acting on TRPM7.

Funding: T.G. and V.C. were supported by the Deutsche Forschungsgemeinschaft (DFG), Transregional Collaborative Research Centre 152.

Conflicts of Interest: The authors declare no conflict of interest.

\section{Abbreviations}

$\begin{array}{ll}\text { AF } & \text { atrial fibrillation } \\ \text { EGF } & \text { epidermal growth factor } \\ \text { EGFR } & \text { epidermal growth factor receptor } \\ \text { EMT } & \text { epithelial-mesenchymal transition } \\ \text { IL } & \text { interleukins } \\ \text { LPS } & \text { lipopolysaccharides } \\ \text { PGE2 } & \text { prostaglandin E2 } \\ \text { PIP2 } & \text { phosphatidylinositol-4,5-bisphosphate } \\ \text { PLC } 2 \text { 2 } & \text { phospholipase C gamma 2 } \\ \text { RhoA } & \text { Ras homolog family member A } \\ \text { SK channels } & \text { small conductance Ca }{ }^{2+} \text {-activated } \mathrm{K}^{+} \text {channels } \\ \text { SOCE } & \text { store-operated calcium entry } \\ \text { TRPM6 } & \text { transient receptor potential cation channel, subfamily M, member } 6 \\ \text { TRPM7 } & \text { transient receptor potential cation channel, subfamily M, member } 7 \\ \text { UUO } & \text { unilateral ureteral obstruction } \\ \text { VSMC } & \text { vascular smooth muscle }\end{array}$




\section{References}

1. Nadler, M.J.; Hermosura, M.C.; Inabe, K.; Perraud, A.L.; Zhu, Q.; Stokes, A.J.; Kurosaki, T.; Kinet, J.P.; Penner, R.; Scharenberg, A.M.; et al. Ltrpc7 is a mg.Atp-regulated divalent cation channel required for cell viability. Nature 2001, 411, 590-595. [CrossRef] [PubMed]

2. Runnels, L.W.; Yue, L.; Clapham, D.E. Trp-plik, a bifunctional protein with kinase and ion channel activities. Science 2001, 291, 1043-1047. [CrossRef] [PubMed]

3. Ryazanov, A.G.; Ward, M.D.; Mendola, C.E.; Pavur, K.S.; Dorovkov, M.V.; Wiedmann, M.; Erdjument-Bromage, H.; Tempst, P.; Parmer, T.G.; Prostko, C.R.; et al. Identification of a new class of protein kinases represented by eukaryotic elongation factor-2 kinase. Proc. Natl. Acad. Sci. USA 1997, 94, 4884-4889. [CrossRef] [PubMed]

4. Zhang, S.; Zhao, D.; Jia, W.; Wang, Y.; Liang, H.; Liu, L.; Wang, W.; Yu, Z.; Guo, F. A bibliometric analysis and review of recent researches on trpm7. Channels 2020, 14, 203-215. [CrossRef]

5. Chubanov, V.; Mittermeier, L.; Gudermann, T. Role of kinase-coupled trp channels in mineral homeostasis. Pharmacol. Ther 2018, 184, 159-176. [CrossRef]

6. Fleig, A.; Chubanov, V. Trpm7. Handb Exp. Pharmacol. 2014, 222, 521-546.

7. Abumaria, N.; Li, W.; Clarkson, A.N. Role of the chanzyme trpm7 in the nervous system in health and disease. Cell Mol. Life Sci 2019, 76, 3301-3310. [CrossRef]

8. Zou, Z.G.; Rios, F.J.; Montezano, A.C.; Touyz, R.M. Trpm7, magnesium, and signaling. Int J. Mol. Sci. 2019, 20, 1877. [CrossRef]

9. Runnels, L.W.; Komiya, Y. Trpm6 and trpm7: Novel players in cell intercalation during vertebrate embryonic development. Dev. Dyn 2020. [CrossRef]

10. Nadolni, W.; Zierler, S. The channel-kinase trpm7 as novel regulator of immune system homeostasis. Cells 2018, 7, 109. [CrossRef]

11. Bates-Withers, C.; Sah, R.; Clapham, D.E. Trpm7, the $\mathrm{mg}(2+)$ inhibited channel and kinase. Adv. Exp. Med. Biol. 2011, 704, 173-183. [PubMed]

12. Chubanov, V.; Ferioli, S.; Wisnowsky, A.; Simmons, D.G.; Leitzinger, C.; Einer, C.; Jonas, W.; Shymkiv, Y.; Bartsch, H.; Braun, A.; et al. Epithelial magnesium transport by trpm6 is essential for prenatal development and adult survival. Elife 2016, 5, e20914. [PubMed]

13. Chubanov, V.; Gudermann, T. Trpm6. Handb. Exp. Pharmacol. 2014, 222, 503-520. [PubMed]

14. Chubanov, V.; Waldegger, S.; Mederos y Schnitzler, M.; Vitzthum, H.; Sassen, M.C.; Seyberth, H.W.; Konrad, M.; Gudermann, T. Disruption of trpm6/trpm7 complex formation by a mutation in the trpm6 gene causes hypomagnesemia with secondary hypocalcemia. Proc. Natl. Acad. Sci. USA 2004, 101, 2894-2899. [PubMed]

15. Mederos y Schnitzler, M.; Waring, J.; Gudermann, T.; Chubanov, V. Evolutionary determinants of divergent calcium selectivity of trpm channels. FASEB J. 2008, 22, 1540-1551. [PubMed]

16. Yamaguchi, H.; Matsushita, M.; Nairn, A.C.; Kuriyan, J. Crystal structure of the atypical protein kinase domain of a trp channel with phosphotransferase activity. Mol. Cell 2001, 7, 1047-1057.

17. Duan, J.; Li, Z.; Li, J.; Hulse, R.E.; Santa-Cruz, A.; Valinsky, W.C.; Abiria, S.A.; Krapivinsky, G.; Zhang, J.; Clapham, D.E. Structure of the mammalian trpm7, a magnesium channel required during embryonic development. Proc. Natl. Acad. Sci. USA 2018, 115, E8201-E8210.

18. Chubanov, V.; Mittermeier, L.; Gudermann, T. Trpm7 reflected in cryo-emirror. Cell Calcium 2018, 76, $129-131$.

19. Hermosura, M.C.; Monteilh-Zoller, M.K.; Scharenberg, A.M.; Penner, R.; Fleig, A. Dissociation of the store-operated calcium current $\mathrm{i}(\mathrm{crac})$ and the mg-nucleotide-regulated metal ion current magnum. J. Physiol. 2002, 539, 445-458.

20. Kozak, J.A.; Kerschbaum, H.H.; Cahalan, M.D. Distinct properties of crac and mic channels in rbl cells. J. Gen. Physiol. 2002, 120, 221-235.

21. Ferioli, S.; Zierler, S.; Zaisserer, J.; Schredelseker, J.; Gudermann, T.; Chubanov, V. Trpm6 and trpm7 differentially contribute to the relief of heteromeric trpm6/7 channels from inhibition by cytosolic $\mathrm{mg}(2+)$ and mg.Atp. Sci. Rep. 2017, 7, 8806. [CrossRef] [PubMed]

22. Ryazanova, L.V.; Rondon, L.J.; Zierler, S.; Hu, Z.; Galli, J.; Yamaguchi, T.P.; Mazur, A.; Fleig, A.; Ryazanov, A.G. Trpm7 is essential for $\mathrm{mg}(2+)$ homeostasis in mammals. Nat. Commun. 2010, 1, 109. [CrossRef] 
23. Sahni, J.; Scharenberg, A.M. Trpm7 ion channels are required for sustained phosphoinositide 3-kinase signaling in lymphocytes. Cell Metab. 2008, 8, 84-93. [CrossRef]

24. Schmitz, C.; Perraud, A.L.; Johnson, C.O.; Inabe, K.; Smith, M.K.; Penner, R.; Kurosaki, T.; Fleig, A.; Scharenberg, A.M. Regulation of vertebrate cellular mg2+ homeostasis by trpm7. Cell 2003, 114, 191-200. [CrossRef]

25. Faouzi, M.; Kilch, T.; Horgen, F.D.; Fleig, A.; Penner, R. The trpm7 channel kinase regulates store-operated calcium entry. J. Physiol. 2017, 595, 3165-3180. [CrossRef] [PubMed]

26. Abiria, S.A.; Krapivinsky, G.; Sah, R.; Santa-Cruz, A.G.; Chaudhuri, D.; Zhang, J.; Adstamongkonkul, P.; DeCaen, P.G.; Clapham, D.E. Trpm7 senses oxidative stress to release $\mathrm{zn}(2+)$ from unique intracellular vesicles. Proc. Natl. Acad. Sci. USA 2017, 114, E6079-E6088. [CrossRef]

27. Su, L.T.; Agapito, M.A.; Li, M.; Simonson, W.T.; Huttenlocher, A.; Habas, R.; Yue, L.; Runnels, L.W. Trpm7 regulates cell adhesion by controlling the calcium-dependent protease calpain. J. Biol. Chem. 2006, 281, 11260-11270. [CrossRef] [PubMed]

28. Wei, C.; Wang, X.; Chen, M.; Ouyang, K.; Song, L.S.; Cheng, H. Calcium flickers steer cell migration. Nature 2009, 457, 901-905. [CrossRef]

29. Clark, K.; Langeslag, M.; van Leeuwen, B.; Ran, L.; Ryazanov, A.G.; Figdor, C.G.; Moolenaar, W.H.; Jalink, K.; van Leeuwen, F.N. Trpm7, a novel regulator of actomyosin contractility and cell adhesion. EMBO J. 2006, 25, 290-301. [CrossRef]

30. Meng, X.; Cai, C.; Wu, J.; Cai, S.; Ye, C.; Chen, H.; Yang, Z.; Zeng, H.; Shen, Q.; Zou, F. Trpm7 mediates breast cancer cell migration and invasion through the mapk pathway. Cancer Lett. 2013, 333, 96-102. [CrossRef]

31. Siddiqui, T.A.; Lively, S.; Vincent, C.; Schlichter, L.C. Regulation of podosome formation, microglial migration and invasion by ca(2+)-signaling molecules expressed in podosomes. J. Neuroinflamm. 2012, 9, 250. [CrossRef] [PubMed]

32. Kuras, Z.; Yun, Y.H.; Chimote, A.A.; Neumeier, L.; Conforti, L. Kca3.1 and trpm7 channels at the uropod regulate migration of activated human t cells. PLoS ONE 2012, 7, e43859. [CrossRef] [PubMed]

33. Su, L.T.; Liu, W.; Chen, H.C.; Gonzalez-Pagan, O.; Habas, R.; Runnels, L.W. Trpm7 regulates polarized cell movements. Biochem. J. 2011, 434, 513-521. [CrossRef] [PubMed]

34. Chen, J.P.; Luan, Y.; You, C.X.; Chen, X.H.; Luo, R.C.; Li, R. Trpm7 regulates the migration of human nasopharyngeal carcinoma cell by mediating ca(2+) influx. Cell Calcium 2010, 47, 425-432. [CrossRef]

35. Desai, B.N.; Krapivinsky, G.; Navarro, B.; Krapivinsky, L.; Carter, B.C.; Febvay, S.; Delling, M.; Penumaka, A.; Ramsey, I.S.; Manasian, Y.; et al. Cleavage of trpm7 releases the kinase domain from the ion channel and regulates its participation in fas-induced apoptosis. Dev. Cell 2012, 22, 1149-1162. [CrossRef]

36. Chen, K.H.; Xu, X.H.; Liu, Y.; Hu, Y.; Jin, M.W.; Li, G.R. Trpm7 channels regulate proliferation and adipogenesis in 3t3-11 preadipocytes. J. Cell Physiol. 2013, 229, 60-67. [CrossRef]

37. Zierler, S.; Yao, G.; Zhang, Z.; Kuo, W.C.; Porzgen, P.; Penner, R.; Horgen, F.D.; Fleig, A. Waixenicin a inhibits cell proliferation through magnesium-dependent block of transient receptor potential melastatin $7(\operatorname{trpm} 7)$ channels. J. Biol. Chem. 2011, 286, 39328-39335. [CrossRef]

38. Zhang, Z.; Wang, M.; Fan, X.H.; Chen, J.H.; Guan, Y.Y.; Tang, Y.B. Upregulation of trpm7 channels by angiotensin ii triggers phenotypic switching of vascular smooth muscle cells of ascending aorta. Circ. Res. 2012, 111, 1137-1146. [CrossRef]

39. Abed, E.; Martineau, C.; Moreau, R. Role of melastatin transient receptor potential 7 channels in the osteoblastic differentiation of murine mc3t3 cells. Calcif. Tissue Int. 2011, 88, 246-253. [CrossRef]

40. Bernhardt, M.L.; Stein, P.; Carvacho, I.; Krapp, C.; Ardestani, G.; Mehregan, A.; Umbach, D.M.; Bartolomei, M.S.; Fissore, R.A.; Williams, C.J. Trpm7 and cav3.2 channels mediate ca(2+) influx required for egg activation at fertilization. Proc. Natl. Acad. Sci. USA 2018, 115, E10370-E10378. [CrossRef]

41. Carvacho, I.; Ardestani, G.; Lee, H.C.; McGarvey, K.; Fissore, R.A.; Lykke-Hartmann, K. Trpm7-like channels are functionally expressed in oocytes and modulate post-fertilization embryo development in mouse. Sci. Rep. 2016, 6, 34236. [CrossRef] [PubMed]

42. Aarts, M.; Iihara, K.; Wei, W.L.; Xiong, Z.G.; Arundine, M.; Cerwinski, W.; MacDonald, J.F.; Tymianski, M. A key role for trpm7 channels in anoxic neuronal death. Cell 2003, 115, 863-877. [CrossRef]

43. Touyz, R.M. Transient receptor potential melastatin 6 and 7 channels, magnesium transport, and vascular biology: Implications in hypertension. Am. J. Physiol. Heart Circ. Physiol. 2008, 294, H1103-H1118. [CrossRef] [PubMed] 
44. Antunes, T.T.; Callera, G.E.; He, Y.; Yogi, A.; Ryazanov, A.G.; Ryazanova, L.V.; Zhai, A.; Stewart, D.J.; Shrier, A.; Touyz, R.M. Transient receptor potential melastatin 7 cation channel kinase: New player in angiotensin ii-induced hypertension. Hypertension 2016, 67, 763-773. [CrossRef]

45. Hermosura, M.C.; Nayakanti, H.; Dorovkov, M.V.; Calderon, F.R.; Ryazanov, A.G.; Haymer, D.S.; Garruto, R.M. A trpm7 variant shows altered sensitivity to magnesium that may contribute to the pathogenesis of two guamanian neurodegenerative disorders. Proc. Natl. Acad. Sci. USA 2005, 102, 11510-11515. [CrossRef]

46. Tseveleki, V.; Rubio, R.; Vamvakas, S.S.; White, J.; Taoufik, E.; Petit, E.; Quackenbush, J.; Probert, L. Comparative gene expression analysis in mouse models for multiple sclerosis, alzheimer's disease and stroke for identifying commonly regulated and disease-specific gene changes. Genomics 2010, 96, 82-91. [CrossRef]

47. Rios, F.J.; Zou, Z.G.; Harvey, A.P.; Harvey, K.Y.; Nosalski, R.; Anyfanti, P.; Camargo, L.L.; Lacchini, S.; Ryazanov, A.G.; Ryazanova, L.; et al. Chanzyme trpm7 protects against cardiovascular inflammation and fibrosis. Cardiovasc. Res. 2020, 116, 721-735. [CrossRef]

48. Sontia, B.; Montezano, A.C.; Paravicini, T.; Tabet, F.; Touyz, R.M. Downregulation of renal trpm7 and increased inflammation and fibrosis in aldosterone-infused mice: Effects of magnesium. Hypertension 2008, 51, 915-921. [CrossRef]

49. Suzuki, S.; Penner, R.; Fleig, A. Trpm7 contributes to progressive nephropathy. Sci. Rep. 2020, 10, 2333. [CrossRef]

50. Du, J.; Xie, J.; Zhang, Z.; Tsujikawa, H.; Fusco, D.; Silverman, D.; Liang, B.; Yue, L. Trpm7-mediated ca2+ signals confer fibrogenesis in human atrial fibrillation. Circ. Res. 2010, 106, 992-1003. [CrossRef]

51. Guilbert, A.; Gautier, M.; Dhennin-Duthille, I.; Haren, N.; Sevestre, H.; Ouadid-Ahidouch, H. Evidence that trpm7 is required for breast cancer cell proliferation. Am. J. Physiol. Cell Physiol. 2009, 297, C493-C502. [CrossRef] [PubMed]

52. Kim, B.J.; Park, E.J.; Lee, J.H.; Jeon, J.H.; Kim, S.J.; So, I. Suppression of transient receptor potential melastatin 7 channel induces cell death in gastric cancer. Cancer Sci. 2008, 99, 2502-2509. [CrossRef]

53. Jiang, J.; Li, M.H.; Inoue, K.; Chu, X.P.; Seeds, J.; Xiong, Z.G. Transient receptor potential melastatin 7-like current in human head and neck carcinoma cells: Role in cell proliferation. Cancer Res. 2007, 67, 10929-10938. [CrossRef] [PubMed]

54. Hanano, T.; Hara, Y.; Shi, J.; Morita, H.; Umebayashi, C.; Mori, E.; Sumimoto, H.; Ito, Y.; Mori, Y.; Inoue, R. Involvement of trpm7 in cell growth as a spontaneously activated ca2+ entry pathway in human retinoblastoma cells. J. Pharmacol. Sci. 2004, 95, 403-419. [CrossRef]

55. Middelbeek, J.; Kuipers, A.J.; Henneman, L.; Visser, D.; Eidhof, I.; van Horssen, R.; Wieringa, B.; Canisius, S.V.; Zwart, W.; Wessels, L.F.; et al. Trpm7 is required for breast tumor cell metastasis. Cancer Res. 2012, 72, 4250-4261. [CrossRef] [PubMed]

56. Rybarczyk, P.; Gautier, M.; Hague, F.; Dhennin-Duthille, I.; Chatelain, D.; Kerr-Conte, J.; Pattou, F.; Regimbeau, J.M.; Sevestre, H.; Ouadid-Ahidouch, H. Transient receptor potential melastatin-related 7 channel is overexpressed in human pancreatic ductal adenocarcinomas and regulates human pancreatic cancer cell migration. Int. J. Cancer 2012, 131, E851-E861. [CrossRef] [PubMed]

57. Chen, Y.F.; Chen, Y.T.; Chiu, W.T.; Shen, M.R. Remodeling of calcium signaling in tumor progression. J. Biomed. Sci. 2013, 20, 23. [CrossRef]

58. Gao, H.; Chen, X.; Du, X.; Guan, B.; Liu, Y.; Zhang, H. Egf enhances the migration of cancer cells by up-regulation of trpm7. Cell Calcium 2011, 50, 559-568. [CrossRef]

59. Romagnani, A.; Vettore, V.; Rezzonico-Jost, T.; Hampe, S.; Rottoli, E.; Nadolni, W.; Perotti, M.; Meier, M.A.; Hermanns, C.; Geiger, S.; et al. Trpm7 kinase activity is essential for t cell colonization and alloreactivity in the gut. Nat. Commun. 2017, 8, 1917. [CrossRef]

60. Stritt, S.; Nurden, P.; Favier, R.; Favier, M.; Ferioli, S.; Gotru, S.K.; van Eeuwijk, J.M.; Schulze, H.; Nurden, A.T.; Lambert, M.P.; et al. Defects in trpm7 channel function deregulate thrombopoiesis through altered cellular $\mathrm{mg}(2+)$ homeostasis and cytoskeletal architecture. Nature Commun. 2016, 7, 11097. [CrossRef]

61. Jin, J.; Desai, B.N.; Navarro, B.; Donovan, A.; Andrews, N.C.; Clapham, D.E. Deletion of trpm7 disrupts embryonic development and thymopoiesis without altering mg2+ homeostasis. Science 2008, 322, 756-760. [PubMed]

62. Elizondo, M.R.; Arduini, B.L.; Paulsen, J.; MacDonald, E.L.; Sabel, J.L.; Henion, P.D.; Cornell, R.A.; Parichy, D.M. Defective skeletogenesis with kidney stone formation in dwarf zebrafish mutant for trpm7. Curr. Biol. 2005, 15, 667-671. [PubMed] 
63. Jin, J.; Wu, L.J.; Jun, J.; Cheng, X.; Xu, H.; Andrews, N.C.; Clapham, D.E. The channel kinase, trpm7, is required for early embryonic development. Proc. Natl. Acad. Sci. USA 2012, 109, E225-E233. [PubMed]

64. Overton, J.D.; Komiya, Y.; Mezzacappa, C.; Nama, K.; Cai, N.; Lou, L.; Fedeles, S.V.; Habas, R.; Runnels, L.W. Hepatocystin is essential for trpm7 function during early embryogenesis. Sci. Rep. 2015, 5, 18395.

65. Sah, R.; Mesirca, P.; Mason, X.; Gibson, W.; Bates-Withers, C.; Van den Boogert, M.; Chaudhuri, D.; Pu, W.T.; Mangoni, M.E.; Clapham, D.E. Timing of myocardial trpm7 deletion during cardiogenesis variably disrupts adult ventricular function, conduction, and repolarization. Circulation 2013, 128, 101-114.

66. Mittermeier, L.; Demirkhanyan, L.; Stadlbauer, B.; Breit, A.; Recordati, C.; Hilgendorff, A.; Matsushita, M.; Braun, A.; Simmons, D.G.; Zakharian, E.; et al. Trpm7 is the central gatekeeper of intestinal mineral absorption essential for postnatal survival. Proc. Natl. Acad. Sci. USA 2019, 116, 4706-4715.

67. Zierler, S.; Sumoza-Toledo, A.; Suzuki, S.; Duill, F.O.; Ryazanova, L.V.; Penner, R.; Ryazanov, A.G.; Fleig, A. Trpm7 kinase activity regulates murine mast cell degranulation. J. Physiol. 2016, 594, 2957-2970.

68. Brandao, K.; Deason-Towne, F.; Zhao, X.; Perraud, A.L.; Schmitz, C. Trpm6 kinase activity regulates trpm7 trafficking and inhibits cellular growth under hypomagnesic conditions. Cell Mol. Life Sci 2014, 71, 4853-4867.

69. Dorovkov, M.V.; Ryazanov, A.G. Phosphorylation of annexin i by trpm7 channel-kinase. J. Biol. Chem. 2004, 279, 50643-50646.

70. Clark, K.; Middelbeek, J.; Lasonder, E.; Dulyaninova, N.G.; Morrice, N.A.; Ryazanov, A.G.; Bresnick, A.R.; Figdor, C.G.; van Leeuwen, F.N. Trpm7 regulates myosin iia filament stability and protein localization by heavy chain phosphorylation. J. Mol. Biol 2008, 378, 790-803.

71. Perraud, A.L.; Zhao, X.; Ryazanov, A.G.; Schmitz, C. The channel-kinase trpm7 regulates phosphorylation of the translational factor eef2 via eef2-k. Cell Signal. 2011, 23, 586-593. [CrossRef] [PubMed]

72. Dorovkov, M.V.; Beznosov, S.N.; Shah, S.; Kotlianskaia, L.; Kostiukova, A.S. [effect of mutations imitating the phosphorylation by trpm7 kinase on the function of the n-terminal domain of tropomodulin]. Biofizika 2008, 53, 943-949. [CrossRef]

73. Deason-Towne, F.; Perraud, A.L.; Schmitz, C. Identification of ser/thr phosphorylation sites in the c2-domain of phospholipase c gamma2 (plcgamma2) using trpm7-kinase. Cell Signal. 2012, 24, 2070-2075. [CrossRef] [PubMed]

74. Voringer, S.; Schreyer, L.; Nadolni, W.; Meier, M.A.; Woerther, K.; Mittermeier, C.; Ferioli, S.; Singer, S.; Holzer, K.; Zierler, S.; et al. Inhibition of trpm7 blocks mrtf/srf-dependent transcriptional and tumorigenic activity. Oncogene 2020, 39, 2328-2344. [CrossRef]

75. Cai, N.; Bai, Z.; Nanda, V.; Runnels, L.W. Mass spectrometric analysis of trpm6 and trpm7 phosphorylation reveals regulatory mechanisms of the channel-kinases. Sci. Rep. 2017, 7, 42739. [CrossRef]

76. Clark, K.; Middelbeek, J.; Morrice, N.A.; Figdor, C.G.; Lasonder, E.; van Leeuwen, F.N. Massive autophosphorylation of the ser/thr-rich domain controls protein kinase activity of trpm6 and trpm7. PLoS ONE 2008, 3, e1876. [CrossRef] [PubMed]

77. Matsushita, M.; Kozak, J.A.; Shimizu, Y.; McLachlin, D.T.; Yamaguchi, H.; Wei, F.Y.; Tomizawa, K.; Matsui, H.; Chait, B.T.; Cahalan, M.D.; et al. Channel function is dissociated from the intrinsic kinase activity and autophosphorylation of trpm7/chak1. J. Biol. Chem. 2005, 280, 20793-20803. [CrossRef] [PubMed]

78. Krapivinsky, G.; Krapivinsky, L.; Manasian, Y.; Clapham, D.E. The trpm7 chanzyme is cleaved to release a chromatin-modifying kinase. Cell 2014, 157, 1061-1072. [CrossRef]

79. Kaitsuka, T.; Katagiri, C.; Beesetty, P.; Nakamura, K.; Hourani, S.; Tomizawa, K.; Kozak, J.A.; Matsushita, M. Inactivation of trpm7 kinase activity does not impair its channel function in mice. Sci Rep. 2014, 4, 5718. [CrossRef]

80. Ryazanova, L.V.; Hu, Z.; Suzuki, S.; Chubanov, V.; Fleig, A.; Ryazanov, A.G. Elucidating the role of the trpm7 alpha-kinase: Trpm7 kinase inactivation leads to magnesium deprivation resistance phenotype in mice. Sci. Rep. 2014, 4, 7599. [CrossRef]

81. Kim, B.J.; Jeon, J.H.; Kim, S.J.; So, I.; Kim, K.W. Regulation of transient receptor potential melastatin 7 (trpm7) currents by mitochondria. Mol. Cells 2007, 23, 363-369. [PubMed]

82. Monteilh-Zoller, M.K.; Hermosura, M.C.; Nadler, M.J.; Scharenberg, A.M.; Penner, R.; Fleig, A. Trpm7 provides an ion channel mechanism for cellular entry of trace metal ions. J. Gen. Physiol. 2003, 121, 49-60. [CrossRef] [PubMed]

83. Prakriya, M.; Lewis, R.S. Separation and characterization of currents through store-operated crac channels and mg2+-inhibited cation (mic) channels. J. Gen. Physiol. 2002, 119, 487-507. [CrossRef] 
84. Chen, X.; Numata, T.; Li, M.; Mori, Y.; Orser, B.A.; Jackson, M.F.; Xiong, Z.G.; MacDonald, J.F. The modulation of trpm7 currents by nafamostat mesilate depends directly upon extracellular concentrations of divalent cations. Mol. Brain 2010, 3, 38. [CrossRef] [PubMed]

85. Parnas, M.; Peters, M.; Dadon, D.; Lev, S.; Vertkin, I.; Slutsky, I.; Minke, B. Carvacrol is a novel inhibitor of drosophila trpl and mammalian trpm7 channels. Cell Calcium 2009, 45, 300-309. [CrossRef]

86. Macianskiene, R.; Martisiene, I.; Zablockaite, D.; Gendviliene, V. Characterization of mg(2)(+)-regulated trpm7-like current in human atrial myocytes. J. Biomed. Sci 2012, 19, 75. [CrossRef]

87. Chen, W.L.; Barszczyk, A.; Turlova, E.; Deurloo, M.; Liu, B.; Yang, B.B.; Rutka, J.T.; Feng, Z.P.; Sun, H.S. Inhibition of trpm7 by carvacrol suppresses glioblastoma cell proliferation, migration and invasion. Oncotarget 2015, 6, 16321-16340. [CrossRef] [PubMed]

88. Chen, W.; Xu, B.; Xiao, A.; Liu, L.; Fang, X.; Liu, R.; Turlova, E.; Barszczyk, A.; Zhong, X.; Sun, C.L.; et al. Trpm7 inhibitor carvacrol protects brain from neonatal hypoxic-ischemic injury. Mol. Brain 2015, 8, 11. [CrossRef]

89. Luo, Y.; Wu, J.Y.; Lu, M.H.; Shi, Z.; Na, N.; Di, J.M. Carvacrol alleviates prostate cancer cell proliferation, migration, and invasion through regulation of pi3k/akt and mapk signaling pathways. Oxid Med. Cell Longev 2016, 2016, 1469693. [CrossRef]

90. Chen, H.C.; Xie, J.; Zhang, Z.; Su, L.T.; Yue, L.; Runnels, L.W. Blockade of trpm7 channel activity and cell death by inhibitors of 5-lipoxygenase. PLoS ONE 2010, 5, e11161. [CrossRef]

91. Kim, B.J.; Nam, J.H.; Kim, S.J. Effects of transient receptor potential channel blockers on pacemaker activity in interstitial cells of cajal from mouse small intestine. Mol. Cells 2011, 32, 153-160. [CrossRef] [PubMed]

92. Kim, B.J.; Kim, S.Y.; Lee, S.; Jeon, J.H.; Matsui, H.; Kwon, Y.K.; Kim, S.J.; So, I. The role of transient receptor potential channel blockers in human gastric cancer cell viability. Can. J. Physiol. Pharmacol. 2012, 90, 175-186. [CrossRef] [PubMed]

93. Mason, M.J.; Schaffner, C.; Floto, R.A.; Teo, Q.A. Constitutive expression of a mg2+-inhibited k+ current and a trpm7-like current in human erythroleukemia cells. Am. J. Physiol. Cell Physiol. 2012, 302, C853-C867. [CrossRef] [PubMed]

94. Chen, J.; Dou, Y.; Zheng, X.; Leng, T.; Lu, X.; Ouyang, Y.; Sun, H.; Xing, F.; Mai, J.; Gu, J.; et al. Trpm7 channel inhibition mediates midazolam-induced proliferation loss in human malignant glioma. Tumour Biol. 2016, 37, 14721-14731. [CrossRef]

95. Dou, Y.; Li, Y.; Chen, J.; Wu, S.; Xiao, X.; Xie, S.; Tang, L.; Yan, M.; Wang, Y.; Lin, J.; et al. Inhibition of cancer cell proliferation by midazolam by targeting transient receptor potential melastatin 7. Oncol. Lett. 2013, 5, 1010-1016. [CrossRef] [PubMed]

96. Kim, B.J.; Nah, S.Y.; Jeon, J.H.; So, I.; Kim, S.J. Transient receptor potential melastatin 7 channels are involved in ginsenoside rg3-induced apoptosis in gastric cancer cells. Basic Clin. Pharmacol. Toxicol 2011, 109, $233-239$. [CrossRef] [PubMed]

97. Kim, B.J. Involvement of melastatin type transient receptor potential 7 channels in ginsenoside rd-induced apoptosis in gastric and breast cancer cells. J. Ginseng Res. 2013, 37, 201-209. [CrossRef]

98. Zhang, Y.; Zhou, L.; Zhang, X.; Bai, J.; Shi, M.; Zhao, G. Ginsenoside-rd attenuates trpm7 and asic1a but promotes asic2a expression in rats after focal cerebral ischemia. Neurol. Sci. 2012, 33, 1125-1131. [CrossRef]

99. Sato-Kasai, M.; Kato, T.A.; Ohgidani, M.; Mizoguchi, Y.; Sagata, N.; Inamine, S.; Horikawa, H.; Hayakawa, K.; Shimokawa, N.; Kyuragi, S.; et al. Aripiprazole inhibits polyi:C-induced microglial activation possibly via trpm7. Schizophr. Res. 2016, 178, 35-43. [CrossRef]

100. Norenberg, W.; Plotz, T.; Sobottka, H.; Chubanov, V.; Mittermeier, L.; Kalwa, H.; Aigner, A.; Schaefer, M. Trpm7 is a molecular substrate of atp-evoked p2x7-like currents in tumor cells. J. Gen. Physiol. 2016, 147, 467-483. [CrossRef]

101. Chubanov, V.; Mederos y Schnitzler, M.; Meissner, M.; Schafer, S.; Abstiens, K.; Hofmann, T.; Gudermann, T. Natural and synthetic modulators of sk (k(ca)2) potassium channels inhibit magnesium-dependent activity of the kinase-coupled cation channel trpm7. Br. J. Pharmacol. 2012, 166, 1357-1376. [CrossRef] [PubMed]

102. Chubanov, V.; Ferioli, S.; Gudermann, T. Assessment of trpm7 functions by drug-like small molecules. Cell Calcium 2017, 67, 166-173. [CrossRef] [PubMed]

103. Chubanov, V.; Schafer, S.; Ferioli, S.; Gudermann, T. Natural and synthetic modulators of the trpm7 channel. Cells 2014, 3, 1089-1101. [CrossRef] 
104. Qin, X.; Yue, Z.; Sun, B.; Yang, W.; Xie, J.; Ni, E.; Feng, Y.; Mahmood, R.; Zhang, Y.; Yue, L. Sphingosine and fty720 are potent inhibitors of the transient receptor potential melastatin 7 (trpm7) channels. Br. J. Pharmacol. 2013, 168, 1294-1312. [PubMed]

105. Hofmann, T.; Schafer, S.; Linseisen, M.; Sytik, L.; Gudermann, T.; Chubanov, V. Activation of trpm7 channels by small molecules under Physiol.ogical conditions. Pflug. Arch. Eur. J. Physiol. 2014, 466, 2177-2189. [CrossRef]

106. Schafer, S.; Ferioli, S.; Hofmann, T.; Zierler, S.; Gudermann, T.; Chubanov, V. Mibefradil represents a new class of benzimidazole trpm7 channel agonists. Pflug. Arch. Eur. J. Physiol. 2016, 468, 623-634.

107. Doukas, J.; Wrasidlo, W.; Noronha, G.; Dneprovskaia, E.; Fine, R.; Weis, S.; Hood, J.; Demaria, A.; Soll, R.; Cheresh, D. Phosphoinositide 3-kinase gamma/delta inhibition limits infarct size after myocardial ischemia/reperfusion injury. Proc. Natl. Acad. Sci. USA 2006, 103, 19866-19871. [CrossRef]

108. Davis, M.I.; Hunt, J.P.; Herrgard, S.; Ciceri, P.; Wodicka, L.M.; Pallares, G.; Hocker, M.; Treiber, D.K.; Zarrinkar, P.P. Comprehensive analysis of kinase inhibitor selectivity. Nat. Biotechnol. 2011, 29, 1046-1051. [CrossRef]

109. Song, C.; Bae, Y.; Jun, J.; Lee, H.; Kim, N.D.; Lee, K.B.; Hur, W.; Park, J.Y.; Sim, T. Identification of tg100-115 as a new and potent trpm7 kinase inhibitor, which suppresses breast cancer cell migration and invasion. Biochim. Biophys. Acta 2017, 1861, 947-957. [CrossRef]

110. Schilling, T.; Miralles, F.; Eder, C. Trpm7 channels regulate proliferation and polarisation of macrophages. J. Cell Sci. 2014, 127, 4561-4566. [CrossRef]

111. Tian, Y.; Yang, T.; Yu, S.; Liu, C.; He, M.; Hu, C. Prostaglandin e2 increases migration and proliferation of human glioblastoma cells by activating transient receptor potential melastatin 7 channels. J. Cell Mol. Med. 2018, 22, 6327-6337. [CrossRef] [PubMed]

112. Tashiro, M.; Inoue, H.; Konishi, M. Physiol.ogical pathway of magnesium influx in rat ventricular myocytes. Biophys. J. 2014, 107, 2049-2058. [CrossRef] [PubMed]

113. Tashiro, M.; Inoue, H.; Konishi, M. Modulation of $\mathrm{mg}(2+)$ influx and cytoplasmic free $\mathrm{mg}(2+)$ concentration in rat ventricular myocytes. J. Physiol. Sci. 2019, 69, 97-102. [CrossRef]

114. Zou, Z.G.; Rios, F.; Neves, K.B.; Alves-Lopes, R.; Ling, J.; Baillie, G.S.; Gao, X.; Fuller, W.; De Lucca Camargo, L.; Gudermann, T.; et al. Epidermal growth factor signaling through transient receptor potential melastatin 7 (trpm7) cation channel regulates vascular smooth muscle cell function. Clin. Sci. 2020, 134, 2019-2035. [CrossRef]

115. Luongo, F.; Pietropaolo, G.; Gautier, M.; Dhennin-Duthille, I.; Ouadid-Ahidouch, H.; Wolf, F.I.; Trapani, V. Trpm6 is essential for magnesium uptake and epithelial cell function in the colon. Nutrients 2018, 10, 784. [CrossRef] [PubMed]

116. Bernhardt, M.L.; Padilla-Banks, E.; Stein, P.; Zhang, Y.; Williams, C.J. Store-operated ca2+ entry is not required for fertilization-induced ca2+ signaling in mouse eggs. Cell Calcium 2017, 65, 63-72. [CrossRef]

117. Souza Bomfim, G.H.; Costiniti, V.; Li, Y.; Idaghdour, Y.; Lacruz, R.S. Trpm7 activation potentiates soce in enamel cells but requires orai. Cell Calcium 2020,87, 102187. [CrossRef]

118. Inoue, H.; Inazu, M.; Konishi, M.; Yokoyama, U. Functional expression of trpm7 as a ca(2+) influx pathway in adipocytes. Physiol. Rep. 2019, 7, e14272. [CrossRef]

119. Siddiqui, T.; Lively, S.; Ferreira, R.; Wong, R.; Schlichter, L.C. Expression and contributions of trpm7 and $\mathrm{kca} 2.3 / \mathrm{sk} 3$ channels to the increased migration and invasion of microglia in anti-inflammatory activation states. PLoS ONE 2014, 9, e106087. [CrossRef]

120. Davis, F.M.; Azimi, I.; Faville, R.A.; Peters, A.A.; Jalink, K.; Putney, J.W., Jr.; Goodhill, G.J.; Thompson, E.W.; Roberts-Thomson, S.J.; Monteith, G.R. Induction of epithelial-mesenchymal transition (emt) in breast cancer cells is calcium signal dependent. Oncogene 2014, 33, 2307-2316. [CrossRef]

121. Krishnamoorthy, M.; Wasim, L.; Buhari, F.H.M.; Zhao, T.; Mahtani, T.; Ho, J.; Kang, S.; Deason-Towne, F.; Perraud, A.L.; Schmitz, C.; et al. The channel-kinase trpm7 regulates antigen gathering and internalization in b cells. Sci. Signal. 2018, 11. [CrossRef] [PubMed]

122. Sisquella, X.; Nebl, T.; Thompson, J.K.; Whitehead, L.; Malpede, B.M.; Salinas, N.D.; Rogers, K.; Tolia, N.H.; Fleig, A.; O'Neill, J.; et al. P. falciparum ligand binding to erythrocytes induce alterations in deformability essential for invasion. eLife 2017, 6, e21083. [CrossRef] [PubMed] 
123. Strobaek, D.; Hougaard, C.; Johansen, T.H.; Sorensen, U.S.; Nielsen, E.O.; Nielsen, K.S.; Taylor, R.D.; Pedarzani, P.; Christophersen, P. Inhibitory gating modulation of small conductance ca2+-activated k+ channels by the synthetic compound (r)-n-(benzimidazol-2-yl)-1,2,3,4-tetrahydro-1-naphtylamine (ns8593) reduces afterhyperpolarizing current in hippocampal ca1 neurons. Mol. Pharmacol. 2006, 70, 1771-1782. [CrossRef] [PubMed]

124. Song, C.; Choi, S.; Oh, K.B.; Sim, T. Suppression of trpm7 enhances trail-induced apoptosis in triple-negative breast cancer cells. J. Cell Physiol. 2020. [CrossRef]

125. Sadowska, A.; Altinay, B.; Hitzl, W.; Ferguson, S.J.; Wuertz-Kozak, K. Hypo-osmotic loading induces expression of il-6 in nucleus pulposus cells of the intervertebral disc independent of trpv4 and trpm7. Front. Pharmacol. 2020, 11, 952. [CrossRef]

126. Diness, J.G.; Sorensen, U.S.; Nissen, J.D.; Al-Shahib, B.; Jespersen, T.; Grunnet, M.; Hansen, R.S. Inhibition of small-conductance ca2+-activated $\mathrm{k}+$ channels terminates and protects against atrial fibrillation. Circ. Arrhythm. ElectroPhysiol. 2010, 3, 380-390. [CrossRef]

127. Qi, X.Y.; Diness, J.G.; Brundel, B.J.; Zhou, X.B.; Naud, P.; Wu, C.T.; Huang, H.; Harada, M.; Aflaki, M.; Dobrev, D.; et al. Role of small-conductance calcium-activated potassium channels in atrial electroPhysiol.ogy and fibrillation in the dog. Circulation 2014, 129, 430-440. [CrossRef]

128. Haugaard, M.M.; Hesselkilde, E.Z.; Pehrson, S.; Carstensen, H.; Flethoj, M.; Praestegaard, K.F.; Sorensen, U.S.; Diness, J.G.; Grunnet, M.; Buhl, R.; et al. Pharmacol.ogic inhibition of small-conductance calcium-activated potassium (sk) channels by ns8593 reveals atrial antiarrhythmic potential in horses. Heart Rhythm 2015, 12, 825-835. [CrossRef]

129. Skibsbye, L.; Poulet, C.; Diness, J.G.; Bentzen, B.H.; Yuan, L.; Kappert, U.; Matschke, K.; Wettwer, E.; Ravens, U.; Grunnet, M.; et al. Small-conductance calcium-activated potassium (sk) channels contribute to action potential repolarization in human atria. Cardiovasc. Res. 2014, 103, 156-167. [CrossRef]

130. Diness, J.G.; Kirchhoff, J.E.; Sheykhzade, M.; Jespersen, T.; Grunnet, M. Antiarrhythmic effect of either negative modulation or blockade of small conductance ca2+-activated $\mathrm{k}+$ channels on ventricular fibrillation in guinea pig langendorff-perfused heart. J. Cardiovasc. Pharmacol. 2015, 66, 294-299. [CrossRef]

131. Fang, L.; Huang, C.; Meng, X.; Wu, B.; Ma, T.; Liu, X.; Zhu, Q.; Zhan, S.; Li, J. Tgf-beta1-elevated trpm7 channel regulates collagen expression in hepatic stellate cells via tgf-beta1/smad pathway. Toxicol. Appl. Pharmacol. 2014, 280, 335-344. [CrossRef] [PubMed]

132. Guo, J.L.; Yu, Y.; Jia, Y.Y.; Ma, Y.Z.; Zhang, B.Y.; Liu, P.Q.; Chen, S.R.; Jiang, J.M. Transient receptor potential melastatin 7 (trpm7) contributes to h2o2-induced cardiac fibrosis via mediating ca(2+) influx and extracellular signal-regulated kinase 1/2 (erk1/2) activation in cardiac fibroblasts. J. Pharmacol. Sci. 2014, 125, 184-192. [CrossRef] [PubMed]

133. Yu, Y.; Chen, S.; Xiao, C.; Jia, Y.; Guo, J.; Jiang, J.; Liu, P. Trpm7 is involved in angiotensin ii induced cardiac fibrosis development by mediating calcium and magnesium influx. Cell Calcium 2014, 55, 252-260. [CrossRef] [PubMed]

134. Zhou, Y.; Yi, X.; Wang, T.; Li, M. Effects of angiotensin ii on transient receptor potential melastatin 7 channel function in cardiac fibroblasts. Exp. Ther. Med. 2015, 9, 2008-2012. [CrossRef]

135. Yogi, A.; Callera, G.E.; O'Connor, S.E.; He, Y.; Correa, J.W.; Tostes, R.C.; Mazur, A.; Touyz, R.M. Dysregulation of renal transient receptor potential melastatin 6/7 but not paracellin-1 in aldosterone-induced hypertension and kidney damage in a model of hereditary hypomagnesemia. J. Hypertens. 2011, 29, 1400-1410. [CrossRef]

136. Meng, Z.; Cao, R.; Wang, Y.; Cao, H.; Liu, T.; Yang, Z.; Wang, X. Suppression of renal trpm7 may alleviate kidney injury in the renal transplantation. World J. Urol. 2014, 32, 1303-1311. [CrossRef]

(C) 2020 by the authors. Licensee MDPI, Basel, Switzerland. This article is an open access article distributed under the terms and conditions of the Creative Commons Attribution (CC BY) license (http://creativecommons.org/licenses/by/4.0/). 